\title{
A APLICAÇÃO DA MEDIAÇÃO À RESOLUÇÃO DE CONFLITOS AMBIENTAIS
}

Silvana Raquel Brendler Colombo

Recebido em 10 de janeiro de 2019 Aceito em 25 de outubro de 2020

\section{RESUMOS DE TESES}

Universidade: Pontifícia Universidade Católica do Paraná

Direito Socioambiental e Desenvolvimento

Programa de Pós-Graduação em Direito

Título: A aplicação da mediação à resolução de conflitos ambientais

Autor: Silvana Raquel Brendler Colombo

Banca examinadora:

Professor Dr. Sérgio Augustin (UCS - RS)

Professor Dr. Egon Bockmann Moreira (UFPR - PR)

Professor. Dr. Luís Alexandre Carta Winter (PUC - PR)

Professora Dra. Jussara Maria Leal de Meirelles (PUC - PR)

Orientador:

Professor Doutor Vladimir Passos de Frietas (PUC - PR)

Co-orientadora: Professora Dra. Laura Jane Ribeiro Garbini Both

\section{Ano da Defesa: 2018}

Resumo: A morosidade do Poder Judiciário, a dificuldade na produção de prova e os questionamentos técnicos são mais onerosos na área ambiental devido à irreversibilidade da quase totalidade dos danos ambientais. Por isso, é preciso pensar em uma alternativa mais célere, eficiente e participativa do que o processo judicial, como a mediação, que é marcada pela autonomia das partes na construção da solução do conflito, o que resulta em maior comprometimento com as obrigações assumidas. Como a definição de método está diretamente relacionada ao problema de pesquisa, às hipóteses e aos objetivos, optou-se como método de abordagem para desenvolver o tema escolhido, o método dedutivo, pois o primeiro capítulo abordou a mediação e os aspectos gerais do marco legal, assim como o segundo capítulo discorreu sobre a Ação Civil Pública, instrumento processual destinado à tutela ambiental, para apresentar nos dois últimos uma proposta de mediação aplicada aos conflitos ambientais. Trata-se de uma pesquisa qualitativa e, nessa perspectiva, depois da leitura da bibliografia selecionada e a revisão bibliográfica, investiu-se na abordagem empírica do objeto. O instrumento de coleta de dados escolhido foi o questionário, com perguntas abertas, para conhecer a opinião dos Magistrados, Promotores de Justiça, Advogados e Professores sobre a mediação ambiental, e levantamento de dados, cuja amostra é de pequena grandeza, sobre as ACPs ambientais julgadas em 2017 junto às Câmaras Reservadas ao meio ambiente do TJ/SP. Verificou-se que as vantagens da mediação em relação à decisão judicial não são apenas identificadas sob a perspectiva quantitativa, traduzida na celeridade, mas também sob a perspectiva qualitativa, maior comprometimento das partes com a solução acordada, pois são elas que detêm o poder de decisão. Concluiuse, também, que a indisponibilidade do direito ao meio ambiente não impede a negociação, não no sentido de renúncia ou disposição sobre o direito, e, sim, em relação à melhor forma de protegê-lo ou concretizá-lo, uma vez que a morosidade na área ambiental pode levá-lo ao perecimento.

Palavras-chave: Mediação. Indisponibilidade. Conflitos ambientais.

Abstract: The slowness of the judiciary, the difficulty in producing evidence and technical questions are more chargeable in the environmental area due to the irreversibility of almost all environmental damage. Therefore, it is necessary to think of a faster, more efficient and participatory alternative than the judicial process, such as mediation is marked by the autonomy of the piece in the construction of the conflict solution, which results 
in a greater commitment to the obligations assumed. In this sense, this research seeks to discuss the object of mediation in order to verify if the unavailable nature of the right to the ecologically balanced environment is an obstacle to the application of this mechanism. As the definition of method is directly related to the research problem, the hypotheses and the objectives, it was chosen as a method of approach to develop the chosen theme, the deductive method, because the first chapter addressed the mediation and general aspects of the legal framework, as well as the second chapter discussed Public Civil Action, a procedural instrument aimed at environmental protection, to present in the last two a proposal for mediation applied to environmental conflicts. It is a qualitative research and, in this perspective, after reading the selected bibliography and the bibliographic review, we invested in the empirical approach of the object. The data collection instrument chosen was the questionnaire, with open questions, to find out the opinion of magistrates, prosecutors, lawyers and teachers on environmental mediation, and data collection, whose sample is small, on environmental ACPs judged in 2017 at the TJ / SP Environment Reserved Chambers. It was found that the advantages of mediation in relation to the judicial decision are not only identified from a quantitative perspective, translated into speed, but also from a qualitative perspective, greater commitment by the parties to the agreed solution, as they are the ones who have the power to decision. It was found that the advantages of mediation in relation to the judicial decision are not only identified from a quantitative perspective, translated into swiftness, but also from a qualitative perspective, a greater commitment of the parties to the agreed solution, since they hold the power of decision. It was concluded that the unavailability of the environment right does not prevent the negotiation, not in the sense of renunciation or disposition on the right, but in relation to the best way to protect it or to materialize it, once that the slowness in the environmental area might lead it to perish.

Keywords: Mediation. Unavailability. Environment conflicts. 